\title{
Association of T1740C polymorphism of $L-F A B P$ with meat quality traits in Junmu No. 1 white swine
}

\author{
Y.H. Zhang ${ }^{1,2}$, L.S. Dai ${ }^{1}$, T.H. Ma ${ }^{1}$, S.Z. Wang ${ }^{3}$, J. Guo ${ }^{2}$, F.J. Li ${ }^{1}$, \\ S.M. Zhang ${ }^{4}$, B.X. Sun ${ }^{2}$, D.F. Liu' ${ }^{1}$, Y. Gao ${ }^{1,2}$ and J.B. Zhang ${ }^{1,2}$ \\ ${ }^{1}$ Laboratory Animal Center, Jilin University, Changchun, Jilin, China \\ ${ }^{2}$ Jilin Provincial Key Laboratory of Animal Embryo Engineering, \\ College of Animal Science and Veterinary Medicine, Jilin University, \\ Changchun, Jilin, China \\ ${ }^{3}$ Department of Animal Science, College of Animal Science and Technology, \\ Inner Mongolia National University, Tongliao, Inner Mongolia, China \\ ${ }^{4}$ Branch of Animal Husbandry, Jilin Academy of Agricultural Science, \\ Gongzhuling, Jilin, China \\ Corresponding authors: J.B. Zhang / Y. Gao \\ E-mail: zjb515@163.com / gyan08@163.com
}

Genet. Mol. Res. 12 (1): 235-241 (2013)

Received January 27, 2012

Accepted July 2, 2012

Published January 30, 2013

DOI http://dx.doi.org/10.4238/2013.January.30.9

\begin{abstract}
This study was designed to investigate a single nucleotide polymorphism in intron 1 of the liver fatty acid-binding protein $(L-F A B P)$ gene in 156 Junmu No. 1 white swine using PCRsingle-strand conformational polymorphism. The association between the polymorphism and meat quality traits was also studied. The cloning and sequencing results indicated that the polymorphism in intron 1 was due to a $\mathrm{T} \rightarrow \mathrm{C}$ mutation at position 1740 of $L-F A B P$, yielding three genotypes (TT, TC, and CC). Association analysis revealed that the polymorphism had a significant effect on marbling $(\mathrm{P}<0.05)$ : genotype $\mathrm{CC}$ had more marbling than TC, and TC had more marbling than TT. The polymorphism also had a highly significant effect on intramuscular fat content $(\mathrm{P}<0.01)$. Genotypes $\mathrm{CC}$ and $\mathrm{TC}$ had higher intramuscular
\end{abstract}


fat content than TT; there was no significant difference between $\mathrm{CC}$ and TC $(\mathrm{P}>0.05)$. However, no significant conclusions concerning other traits could be drawn. We tentatively conclude that $L-F A B P$ is a candidate gene or a quantitative trait locus-linked gene associated with meat quality traits.

Key words: Swine; $L-F A B P$; Intron 1; Single nucleotide polymorphism; Marbling; Intramuscular fat

\section{INTRODUCTION}

Geneticists are working to improve meat quality traits in pigs using genetic manipulation to control important genes in vivo. This study is of particular importance for a healthy diet in China, where large amounts of pork are consumed. Some genes play important roles in metabolic pathways, and many genes that are involved in the growth and development of animals require more detailed study (Curi et al., 2009). Liver fatty acid-binding protein (L-FABP) is a member of the FABP multigene family; FAPBs are small intracellular polypeptides found in many tissues involved in fatty acid transfer and metabolism, and are encoded by various genes (Gomez et al., 2007). L-FABP is present in hepatocytes and small intestine mucosa cell cytoplasm. In mammals, L-FABP is expressed in both the liver and small intestine (Di Pietro and Santomé, 1996) and to a much lesser extent in the kidney (Rolf et al., 1995). It can bind not only fatty acids but also a wide range of hydrophobic ligands, such as acyl-CoAs, bilirubin, lysophosphatidylcholine, retinoic acid, bile salts, prostaglandins, heme, and peroxisome proliferators (Glatz and van der Vusse, 1996). To date, the primary structures of L-FABPs from rat, human, cow, and pig have been reported, and these proteins display $79-90 \%$ amino acid identity (Di Pietro et al., 1999). The L-FABP gene, which influences the uptake, transport, mitochondrial oxidation, and esterification of fatty acids (Atshaves et al., 2004; Jiang et al., 2006), has been suggested as a candidate gene for meat quality traits. Therefore, studying the genetic variance of the $L-F A B P$ gene could lead to improvements in the quality of pork.

The pig is an important genetic, genomic, and biochemical model in scientific studies (Liu et al., 2010). Junmu No. 1 white swine are fast growing, and with high forage availability and adaptability; these traits make the pigs suitable for raising in north China. As far as we are aware, no molecular genetic research has been carried out on the association of $L-F A B P$ with production performance in Junmu No. 1 white swine. Consequently, this study is the first to investigate genetic variation through PCR-single-strand conformation polymorphism (PCRSSCP) and sequencing, as well as the association of the gene with production performance in this breed of pig. The aim of this research was to identify gene markers for improved meat quality traits in Junmu No. 1 white swine.

\section{MATERIAL AND METHODS}

\section{Animals and DNA extraction}

Blood samples from 156 Junmu No. 1 white swine were collected from the breeding farm in the Agronomy Ministry of Jilin University; rearing and feeding conditions were standardized. The samples were stored at $-20^{\circ} \mathrm{C}$ after treatment with ethylenediamine tetraacetic 
acid. Genomic DNA was extracted according to the protocol of Sambrook et al. (1989) and detected with $1 \%$ agarose gel electrophoresis.

\section{Primer design}

The primers were designed according to the GenBank L-FABP sequence (accession No. DQ182323). The upstream primer was 5'-CCCCTCAGCCTCCAATGCCT-3' and the downstream primer was 5'-CTTGACCTTCTCCCCAGTCA-3'. The primers were synthesized by Shanghai Sangon Biological Engineering Technology \& Services Co. Ltd. (China).

\section{PCR amplification}

The PCR mixture contained $50 \mathrm{ng}$ DNA template, $10 \mathrm{pmol} / \mu \mathrm{L}$ upstream or downstream primer, $2.5 \mathrm{mM}$ dNTP mixture, $1.5 \mathrm{mM} \mathrm{MgCl}_{2}$, and $1 \mathrm{U}$ Taq DNA polymerase in a $50-\mu \mathrm{L}$ reaction volume. Amplification conditions were as follows: denaturation at $94^{\circ} \mathrm{C}$ for 5 min, 35 cycles of amplification at $94^{\circ} \mathrm{C}$ for $30 \mathrm{~s}, 59^{\circ} \mathrm{C}$ for $45 \mathrm{~s}, 72^{\circ} \mathrm{C}$ for $1 \mathrm{~min}$, and an extension step at $72^{\circ} \mathrm{C}$ for $10 \mathrm{~min}$. The amplification products were detected using $1.5 \%$ agarose gel electrophoresis and visualized using a UV transilluminator.

\section{Genetic variation identification and sequencing}

The PCR products from 156 pigs were genotyped using 12\% native polyacrylamide gel electrophoresis (PAGE; $150 \mathrm{~V}, 16 \mathrm{~h}$ ). The PCR product $(2 \mu \mathrm{L})$ was mixed with $5 \mu \mathrm{L}$ loading buffer. PCR products were denatured for $10 \mathrm{~min}$ at $98^{\circ} \mathrm{C}$ and the mixture was immediately cooled on ice for $10 \mathrm{~min}$. The denatured samples were loaded on a $12 \%$ polyacrylamide gel through a microinjector. After electrophoresis, the gel was shaken gently for $10-15 \mathrm{~min}$ in $70 \%$ ethanol and for 20 min in $\mathrm{AgNO}_{3}$ staining solution after washing with double-distilled water. Washing was repeated three times after incubation in the staining solution. Coloration solution was added until bands became clearly visible. The reaction was terminated by washing the gel. A refrigerated circulator was used to control the temperature $\left(4^{\circ} \mathrm{C}\right)$ of the gels.

PCR products exhibiting homozygous genotypes were cloned and sequenced by Shanghai Sangon Biological Engineering Technology \& Services Co., Ltd. The DNAMAN software package (USA) was used to confirm the $L-F A B P$ DNA sequence and detect the polymorphic locus.

\section{Measurement of meat quality traits and statistics}

The methods used to assess meat quality are listed in Table 1. Genotypic and allelic frequencies were determined, and a $\chi^{2}$ test for Junmu No. 1 white swine was performed. Associations between genotypes and meat quality traits were analyzed using the general linear model procedure of SPSS version 13.0. The linear model was:

$$
\mathrm{Y}_{\mathrm{ijklm}}=\mu+\mathrm{A}_{\mathrm{i}}+\mathrm{B}_{\mathrm{j}}+\mathrm{G}_{\mathrm{k}}+\mathrm{P}_{1}+\mathrm{S}_{\mathrm{m}}+\mathrm{E}_{\mathrm{ijklm}},
$$

where $Y_{i j k m}$ is the observation of meat quality trait, $\mu$ is the overall population mean, $A_{i}$ is the fixed effect due to the $\mathrm{i}^{\text {th }}$ age, $B_{j}$ is the fixed effect of the $\mathrm{j}^{\text {th }}$ slaughter batch, $G_{k}$ is the fixed effect associated with the $\mathrm{k}^{\text {th }}$ genotype (TT, TC, and CC genotypes), $P_{l}$ is the fixed effect of 
sire pedigree $1, S_{m}$ is the fixed effect associated with sex, and $E_{i j k l m}$ is a random error term. The significance of differences was tested using the Duncan multiple comparison.

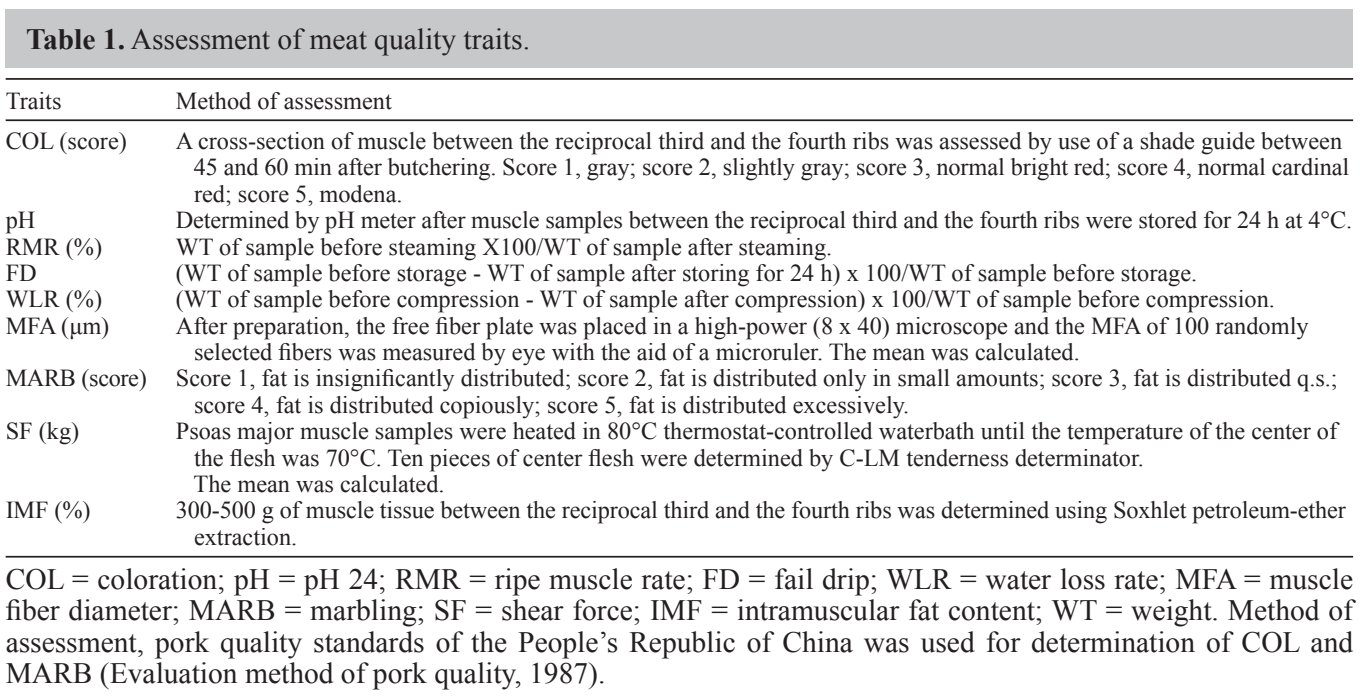

\section{RESULTS}

\section{Polymorphism of the $L-F A B P$ gene and the $\chi^{2}$ test}

Three different genotypes designated TT, TC, and CC were identified in the pig population using PCR-SSCP. The TT and CC genotypes produced two bands and the TC genotype produced three bands (Figure 1A). The genotypic frequency of TC in $L-F A B P$ was 0.52 , and that of TT (0.31) was higher than that of CC (0.17; Table 2). The frequencies of alleles T and $\mathrm{C}$ were 0.57 and 0.43 , respectively (Table 2 ). The $\chi^{2}$ test showed that the population of Junmu No. 1 white swine was in Hardy-Weinberg equilibrium (HWE) for the polymorphism in the $L-F A B P$ gene $\left(\chi^{2}=0.004, \mathrm{P}>0.05\right)$.

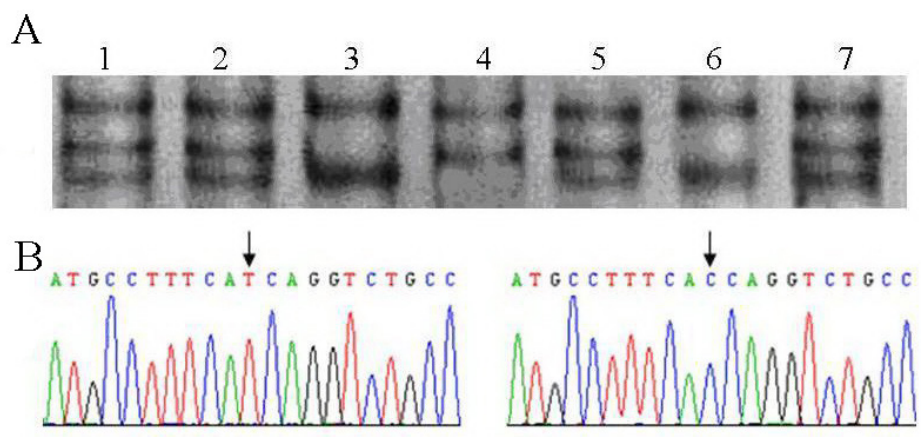

Figure 1. A. Electrophoresis patterns of PCR-SSCP intron 1 of the Junmu No. 1 white swine $L$-FABP gene. Lanes $1,2,5$, and $7=\mathrm{TC}$ genotype; lanes 3 and $6=\mathrm{TT}$ genotype; lane $4=\mathrm{CC}$ genotype. B. Chromatograms showing mutations at intron 1 of the Junmu No. 1 white swine $L-F A B P$ gene. 
Table 2. Gene and genotypic frequencies of the $L-F A B P$ gene in Junmu No. 1 white swine.

\begin{tabular}{|c|c|c|c|c|c|c|}
\hline \multirow[t]{2}{*}{$\mathrm{N}_{1}$} & \multicolumn{2}{|c|}{ Gene frequency } & \multicolumn{3}{|c|}{ Genotypic frequency $\left(\mathrm{N}_{2}\right)$} & \multirow[t]{2}{*}{$\chi^{2}$ (HWE) } \\
\hline & $\mathrm{T}$ & $\mathrm{C}$ & TT & $\mathrm{TC}$ & $\mathrm{CC}$ & \\
\hline 156 & 0.57 & 0.43 & $0.31(48)$ & $0.52(82)$ & $0.17(26)$ & 0.004 \\
\hline
\end{tabular}

\section{Sequencing}

The results of PCR fragment sequencing of the representative homozygous genotypes revealed a point mutation at position 1740 of $L-F A B P$. The sequencing figures of the homozygous genotypes are shown in Figure 1B.

\section{Association between different $L-F A B P$ genotypes and meat quality traits}

The single nucleotide polymorphism exhibited statistically significant associations with marbling and with intramuscular fat (IMF) content, but not with other traits in Junmu No. 1 white swine (Table 3). The differences between the TT (marbling, 2.051), TC (marbling, 2.319), and CC (marbling, 2.643) genotypes were significant $(\mathrm{P}<0.05)$. Genotype CC (2.765) and TC (2.719) had higher IMF measurements than genotype TT $(2.216)(\mathrm{P}<0.01)$, but there was no significant difference between the $\mathrm{CC}$ and TC genotypes $(\mathrm{P}>0.05)$.

Table 3. Least squares analysis of different genotypes with meat quality traits in intron 1 of $L-F A B P$.

\begin{tabular}{|c|c|c|c|c|c|}
\hline \multirow[t]{3}{*}{ Traits } & \multicolumn{3}{|c|}{ Genotypes } & \multirow[t]{3}{*}{$\mathrm{F}$} & \multirow[t]{3}{*}{$\mathrm{P}$} \\
\hline & $\mathrm{TT}$ & $\mathrm{TC}$ & $\mathrm{CC}$ & & \\
\hline & $\mathrm{LSM} \pm \mathrm{SE}$ & $\mathrm{LSM} \pm \mathrm{SE}$ & $\mathrm{LSM} \pm \mathrm{SE}$ & & \\
\hline COL (score) & $3.257 \pm 0.096$ & $3.208 \pm 0.109$ & $3.243 \pm 0.116$ & 0.029 & 0.973 \\
\hline $\mathrm{pH}$ & $5.564 \pm 0.063$ & $5.681 \pm 0.085$ & $5.584 \pm 0.106$ & 1.712 & 0.201 \\
\hline RMR (\%) & $59.964 \pm 1.267$ & $60.634 \pm 1.378$ & $61.045 \pm 1.615$ & 0.676 & 0.583 \\
\hline FD & $2.341 \pm 0.279$ & $2.416 \pm 0.258$ & $2.613 \pm 0.264$ & 1.224 & 0.318 \\
\hline WLR (\%) & $36.487 \pm 0.756$ & $34.964 \pm 0.864$ & $35.613 \pm 1.056$ & 0.461 & 0.633 \\
\hline $\operatorname{MFA}(\mu \mathrm{m})$ & $40.125 \pm 0.981$ & $41.034 \pm 1.086$ & $39.968 \pm 0.948$ & 0.341 & 0.827 \\
\hline MARB (score) & $2.051 \pm 0.613^{\mathrm{a}}$ & $2.319 \pm 0.515^{\mathrm{b}}$ & $2.643 \pm 0.491^{\mathrm{c}}$ & 4.458 & 0.020 \\
\hline $\mathrm{SF}(\mathrm{kg})$ & $21.368 \pm 1.063$ & $20.986 \pm 1.207$ & $21.674 \pm 1.162$ & 0.276 & 0.761 \\
\hline IMF (\%) & $2.216 \pm 0.066^{\mathrm{a}}$ & $2.719 \pm 0.061^{\mathrm{b}}$ & $2.765 \pm 0.059^{\mathrm{b}}$ & 46.298 & 0.000 \\
\hline
\end{tabular}

$\mathrm{COL}=$ coloration; $\mathrm{pH}=\mathrm{pH} 24 ; \mathrm{RMR}=$ ripe muscle rate $\mathrm{FD}=$ fail drip $\mathrm{WLR}=$ water loss rate; $\mathrm{MFA}=$ muscle fiber diameter; MARB = marbling; $\mathrm{SF}=$ shear force; IMF = intramuscular fat content. $\mathrm{LSM}=$ least square mean; $\mathrm{SE}=$ standard error. In the same row, means without a common superscript letter differ $(\mathrm{P}<0.05)$.

\section{DISCUSSION}

Hereditary features and characteristics of pig breeds are formed through continual selection under both natural and anthropogenic conditions. The $\chi^{2}$ fitness test indicated that the Junmu No. 1 white swine population was in HWE, probably the result of long-term natural and artificial selection. Generally, the more extensively varied the hereditary basis and the lower the purity of varieties, the more abundant is DNA polymorphism. A single base substi- 
tution was found within intron 1 of the Junmu No. 1 white swine gene $L$-FABP. The genetic polymorphism could be due to the relatedness of Junmu No. 1 white swine to the Three River white pig and Shi Ge pig. Herein, we present evidence that the mutation is associated with enhanced IMF and increased marbling.

IMF content refers to the deposits of fat within muscles (Jurie et al., 2007) that affect the sensory properties and nutritional value of meats (Geay et al., 2001). The suggested optimal range of IMF content for achieving eating satisfaction and meeting dietetic requirements is $2.5-3.0 \%$ ( $\mathrm{Li}$ et al., 2010). There was a significant influence of the $L-F A B P$ gene polymorphism on IMF in Junmu No. 1 white swine. Animals with the $\mathrm{C}$ allele in this breed had significantly better performances with regard to IMF.

The effect of the $L-F A B P$ polymorphism on IMF accretion could be due to the physicochemical properties and function of $L-F A B P$. There are considerable data supporting the idea that L-FABP is structurally and functionally different from other FABP types: it binds two fatty acids per molecule (Thompson et al., 1997), whereas the other FABP types have a single-fatty acid-binding site (Richieri et al., 1994); and unlike other FABPs, it undergoes a significant conformational change upon fatty acid binding (Nemecz et al., 1991). L-FABP is involved in the intake and intracellular transport of long-chain fatty acids and very long-chain fatty acids (Gertow et al., 2004), influencing the deposition of IMF.

This study confirms that the $L-F A B P$ locus is involved in the regulation of IMF accretion, which agrees with the results of Jiang et al. (2006). In our pig population, the effects on IMF might be due to linkage disequilibrium between the investigated $L-F A B P$ loci and one or more other loci.

Marbling plays a key role in establishing the quality of pork (Switonski et al., 2010). Kamalakar et al. (2009) found that marbling is positively related to pork tenderness. Other studies have shown a positive correlation between marbling and juiciness (Heyer and Lebret, 2007). To date, there has been no report about the association between polymorphisms in the $L-F A B P$ gene and marbling in pigs. Findings from our study of Junmu No. 1 white swine support the association of $L-F A B P$ genetic variation with marbling. Animals with the $\mathrm{C}$ allele in this breed have significantly better performances on marbling. The presently known polymorphism in the $L-F A B P$ gene can be used in marker-assisted selection to improve the marbling of pork.

The current study led us to hypothesize that $L-F A B P$ is a candidate gene or a quantitative trait locus-linked gene associated with pork quality. For Junmu No. 1 white swine, it appears that the main task is to protect the genetic resource of high IMF content so that it may provide valuable experimental materials for further research on the $L-F A B P$ gene.

\section{ACKNOWLEDGMENTS}

Research supported by the Tackle Key Problems in Science and Technology Program from Jilin Province (\#09ZDGG008) and the Technology and Innovative Platform about Engineering and Imitating Creature in "985 Engineering".

\section{REFERENCES}

Atshaves BP, McIntosh AM, Lyuksyutova OI, Zipfel W, et al. (2004). Liver fatty acid-binding protein gene ablation inhibits branched-chain fatty acid metabolism in cultured primary hepatocytes. J. Biol. Chem. 279: 30954-30965.

Curi RA, Chardulo LA, Mason MC, Arrigoni MD, et al. (2009). Effect of single nucleotide polymorphisms of CAPN1 
and CAST genes on meat traits in Nellore beef cattle (Bos indicus) and in their crosses with Bos taurus. Anim. Genet. 40: $456-462$.

Di Pietro SM and Santomé JA (1996). Presence of two new fatty acid binding proteins in catfish liver. Biochem. Cell Biol. 74: 675-680.

Di Pietro SM, Veerkamp JH and Santomé JA (1999). Isolation, amino acid sequence determination and binding properties of two fatty-acid-binding proteins from axolotl (Ambistoma mexicanum) liver. Evolutionary relationship. Eur. J. Biochem. 259: 127-134.

Geay Y, Bauchart D, Hocquette JF and Culioli J (2001). Effect of nutritional factors on biochemical, structural and metabolic characteristics of muscles in ruminants, consequences on dietetic value and sensorial qualities of meat. Reprod. Nutr. Dev. 41: 1-26.

Gertow K, Bellanda M, Eriksson P, Boquist S, et al. (2004). Genetic and structural evaluation of fatty acid transport protein-4 in relation to markers of the insulin resistance syndrome. J. Clin. Endocrinol. Metab. 89: 392-399.

Glatz JF and van der Vusse GJ (1996). Cellular fatty acid-binding proteins: their function and physiological significance. Prog. Lipid Res. 35: 243-282.

Gomez LC, Real SM, Ojeda MS, Gimenez S, et al. (2007). Polymorphism of the FABP2 gene: a population frequency analysis and an association study with cardiovascular risk markers in Argentina. BMC Med. Genet. 8: 39.

Heyer A and Lebret B (2007). Compensatory growth response in pigs: effects on growth performance, composition of weight gain at carcass and muscle levels, and meat quality. J. Anim. Sci. 85: 769-778.

Jiang YZ, Li XW and Yang GX (2006). Sequence characterization, tissue-specific expression and polymorphism of the porcine (Sus scrofa) liver-type fatty acid binding protein gene. Yi Chuan Xue Bao 33: 598-606.

Jurie C, Cassar-Malek I, Bonnet M, Leroux C, et al. (2007). Adipocyte fatty acid-binding protein and mitochondrial enzyme activities in muscles as relevant indicators of marbling in cattle. J. Anim. Sci. 85: 2660-2669.

Kamalakar RB, Chiba LI, Divakala KC, Rodning SP, et al. (2009). Effect of the degree and duration of early dietary amino acid restrictions on subsequent and overall pig performance and physical and sensory characteristics of pork. J. Anim. Sci. 87: 3596-3606.

Li X, Kim SW, Choi JS, Lee YM, et al. (2010). Investigation of porcine FABP3 and LEPR gene polymorphisms and mRNA expression for variation in intramuscular fat content. Mol. Biol. Rep. 37: 3931-3939.

Liu K, Wang G, Zhao SH, Liu B, et al. (2010). Molecular characterization, chromosomal location, alternative splicing and polymorphism of porcine GFAT1 gene. Mol. Biol. Rep. 37: 2711-2717.

Nemecz G, Jefferson JR and Schroeder F (1991). Polyene fatty acid interactions with recombinant intestinal and liver fatty acid-binding proteins. Spectroscopic studies. J. Biol. Chem. 266: 17112-17123.

Richieri GV, Ogata RT and Kleinfeld AM (1994). Equilibrium constants for the binding of fatty acids with fatty acidbinding proteins from adipocyte, intestine, heart, and liver measured with the fluorescent probe ADIFAB. J. Biol. Chem. 269: 23918-23930.

Rolf B, Oudenampsen-Krüger E, Börchers T, Faergeman NJ, et al. (1995). Analysis of the ligand binding properties of recombinant bovine liver-type fatty acid binding protein. Biochim. Biophys. Acta 1259: 245-253.

Sambrook J, Fritsch EF and Maniatis T (1989). Molecular Cloning: A Laboratory Manual. 2nd edn. Cold Spring Harbor Laboratory Press, New York.

Switonski M, Stachowiak M, Cieslak J, Bartz M, et al. (2010). Genetics of fat tissue accumulation in pigs: a comparative approach. J. Appl. Genet. 51: 153-168.

Thompson J, Winter N, Terwey D, Bratt J, et al. (1997). The crystal structure of the liver fatty acid-binding protein. A complex with two bound oleates. J. Biol. Chem. 272: 7140-7150. 